\title{
The Effect of Nickel on a Marine Bacterium: Fine Structure of Arthrobacter marinus
}

\author{
By A. B. COBET* AND G. E. JONES \\ Department of Microbiology, University of New Hampshire \\ Durham, New Hampshire 03824, U.S.A. \\ AND J. ALBRIGHT, HELEN SIMON AND C. WIRSEN \\ Department of Biology, Boston University, Boston, Massachusetts 02215, U.S.A.
}

(Accepted for publication 24 March 197I)

\begin{abstract}
SUMMARY
Rod-shaped Arthrobacter marinus, normally $2 \times 4 \mu \mathrm{m}$., enlarged to Io to I $5 \mu \mathrm{m}$. diam. after $6 \mathrm{~h}$. growth with $4 \times \mathrm{IO}^{-4} \mathrm{M}-\mathrm{NiCl}_{2}$. Electron microscopy of ultra-thin sections showed a greatly plasmolysed megalomorph with the space originating at the poles after $\mathrm{I}$ to $\mathbf{2} \mathrm{h}$. Nuclear material retained its filamentous structure and the number of its loci increased; ribosomal material did not change in density, size or arrangement. The inner dense layer of the wall disappeared, leaving a dense-lightdense profile; the cytoplasmic membrane remained unchanged. Accumulated mesosomes may have accounted for the high degree of reticulation in the cytoplasm. Blebs of 0.05 to $0.1 \mu \mathrm{m}$. diam. on the exterior of the wall, delineated by a double membrane, appear to originate from the outer membrane.
\end{abstract}

\section{INTRODUCTION}

Nickel is responsible for morphological changes in muscle cells in tissue culture (Bassur \& Gilman, 1967), and for ultrastructural changes in pulmonary alveoli (Hackett \& Sunderman, 1968) and hepatic parenchymal cells (Hackett \& Sunderman, 1969) of rats. Pronounced enlargement of the marine bacterium Arthrobacter marinus occurred during growth with nickel, the effect being proportional to the nickel concentration up to $4 \times 10^{-4} \mathrm{M}$, the highest in which reproduction occurred (Cobet, Wirsen \& Jones, 1970). The enlargement process and examination by electron microscopy of these morphological changes are described here.

\section{METHODS}

Organism and growth conditions. The stock culture of Arthrobacter marinus (ATCC 25374) was transferred every 6 weeks on marine agar slants (Difco Laboratory, Detroit, Michigan, U.S.A.), incubated at ambient temperature $\left(23^{\circ}\right.$ to $\left.27^{\circ}\right)$ for $24 \mathrm{~h}$. and then stored at $4^{\circ}$ to $6^{\circ}$.

Organisms were prepared for microscopy by transferring an $18 \mathrm{~h}$. culture to a medium of the following composition: peptone (Difco), 0.5 g.; yeast extract (Difco), 0.5 g.; ferric ammonium citrate, 0.01 g.; synthetic sea water (Lyman \& Fleming, I940), 750 ml.; distilled water, $250 \mathrm{ml}$. The final $\mathrm{pH}$ was 7.8 to 8.0 after autoclaving at $\mathbf{2} 2 \mathrm{I}^{\circ}$ for $\mathrm{I} 5 \mathrm{~min}$. After incubation at ambient temperature for $3 \mathrm{~h}$. on a gyrotory shaker at $300 \mathrm{rev} . / \mathrm{min}$. $\mathrm{NiCl}_{2}$ was added to $4 \times 10^{-4} \mathrm{M}$-nickel. Samples were removed $\mathrm{I}, 2,3$ and $6 \mathrm{~h}$. later and prepared for electron microscopy.

* Present address: Naval Medical Research Unit no. I, University of California, Berkeley, California 94720 , U.S.A. 
Electron microscopy. To each sample redistilled glutaraldehyde (Eastman Chemical Co., Rochester, New York, U.S.A.) was added to $0.76 \%$ and the organisms fixed for $3 \mathrm{~h}$. at $6^{\circ}$. They were centrifuged at $1500 \mathrm{rev} . / \mathrm{min}$. for Io $\mathrm{min}$., washed twice with synthetic sea water and embedded in $\mathrm{I} \cdot 0 \%$ Oxoid ion agar (Colab Laboratories, Illinois, U.S.A.), also prepared in synthetic sea water. The embedded material was cut into I to $2 \mathrm{~mm} .^{3}$ blocks and left overnight in $\mathrm{I} \cdot 0 \%$ osmic acid in veronal buffer at $\mathrm{pH} 6 \cdot \mathrm{I}$ (Ryter \& Kellenberger, I958). All components of the veronal buffer were prepared with synthetic sea water to maintain osmotic support. The blocks were washed twice for $30 \mathrm{~min}$. in the modified veronal buffer, then placed for $2 \mathrm{~h}$. in $0.5 \%$ uranyl acetate prepared in the modified veronal buffer. The blocks were again washed twice in the buffer and dehydrated through 50, 70, 90, 95 and $100 \%$ ethyl alcohol each for $30 \mathrm{~min}$. in an ice bath. The absolute alcohol was changed twice to ensure complete dehydration.

The dehydrated material was placed twice for $10 \mathrm{~min}$. in propylene oxide and then overnight in propylene oxide-epon mixture $(\mathrm{I}: \mathrm{I})$ in an open vial. The epon mixture was prepared from equal volumes of mixture A and B, plus $\mathrm{I} \cdot 5 \% 2,4,6$-tri (dimethylaminomethyl) phenol. Mixture A was prepared with $64 \mathrm{ml}$. epon resin 812 and $100 \mathrm{ml}$. dodecenylsuccinic anhydride and mixture B with $100 \mathrm{ml}$. epon resin 812 and $89 \mathrm{ml}$. malic methyl anhydride. The infiltrated agar blocks were transferred to size number o empty gelatin capsules for embedding in the epon mixture. The filled capsules were then placed in a 12 to $13 \mathrm{lb}$ vacuum for $2 \mathrm{~h}$. at ambient temperature. After returning to atmospheric pressure, the agar blocks were arranged in the epon and replaced under vacuum at $60^{\circ}$ for 2 days.

Ultra-thin sections were cut with a glass knife in an LKB ultramicrotome. The sections were placed on a 200 or 300 mesh copper grid, stained with uranyl acetate and lead citrate and observed in a Siemann's Elmskop I using the double condenser system, a $200 \mu \mathrm{m}$. condenser aperture, a $40 \mu \mathrm{m}$. objective aperture and an accelerating voltage of $80 \mathrm{kV}$. Electron micrographs were recorded on Eastmen Kodak contrast projector slide plates.

Phase photomicrography. The bacteria, prepared as wet mounts, were observed under phase-contrast in a Zeiss WL optical microscope and photomicrographs were recorded with a Reichert camera attachment using Kodak Tri-X film.

Abbreviations: AS, adhering structure; B, bleb; CW, cell wall; I, intracellular space; $\mathrm{M}$, mesosome; MP, mucopeptide; $\mathrm{N}$, nucleus; PM, plasma membrane; $\mathrm{R}$, ribosomes; Ret, reticulation; $\mathrm{S}$, septum. Scale marker represents $0.5 \mu \mathrm{m}$.

\section{Plate I}

Fig. I to 8. Cellular development of Arthrobacter marinus grown in medium containing $4 \times 1 \mathrm{IO}^{-4} \mathrm{M}^{-}$ $\mathrm{NiCl}_{2}$ at $25^{\circ}$. At times indicated photomicrographs were prepared from wet mounts using phase contrast. $\times 2000$.

Fig. I. Inoculum, I $8 \mathrm{~h}$. culture from marine agar slant.

Fig. 2. After $4.5 \mathrm{~h}$. incubation in nutrient medium without added nickel.

Fig. 3. After $0.5 \mathrm{~h}$. incubation in presence of nickel.

Fig. 4. After $1.5 \mathrm{~h}$. incubation in presence of nickel.

Fig. 5. After $2.5 \mathrm{~h}$. incubation in presence of nickel.

Fig. 6. After $4.5 \mathrm{~h}$. incubation in presence of nickel.

Fig. 7. After $6.5 \mathrm{~h}$. incubation in presence of nickel.

Fig. 8. After $10.5 \mathrm{~h}$. incubation in presence of nickel.

Fig. 9. Longitudinal section through a $A$. marinus grown for $3 \mathrm{~h}$. at $25^{\circ}$ in the absence of nickel.

Fig. 10. Partial cross-section of a A. marinus cell grown for $3 \mathrm{~h}$. at $25^{\circ}$ in the absence of nickel showing the origin of the blebs. 

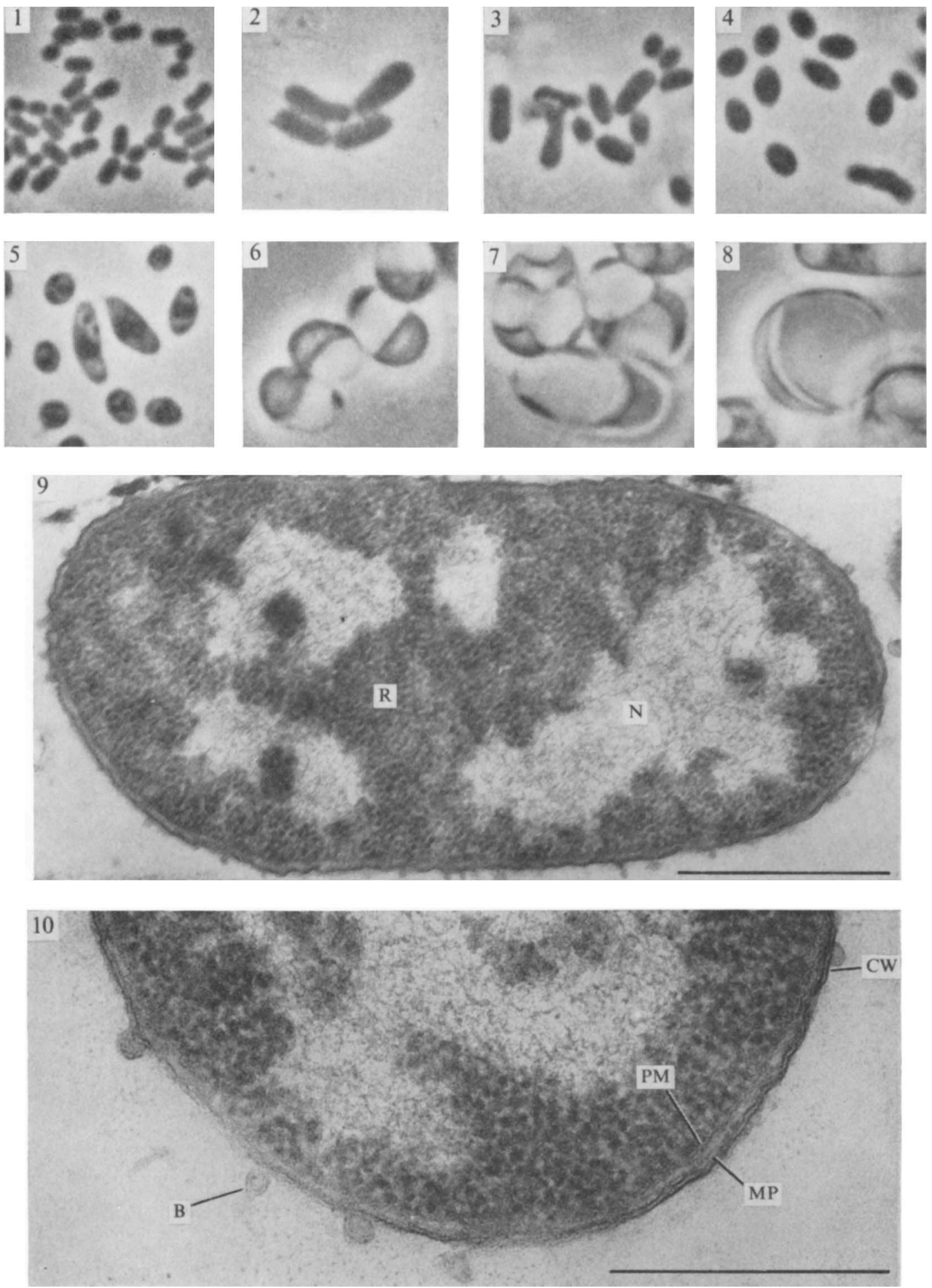

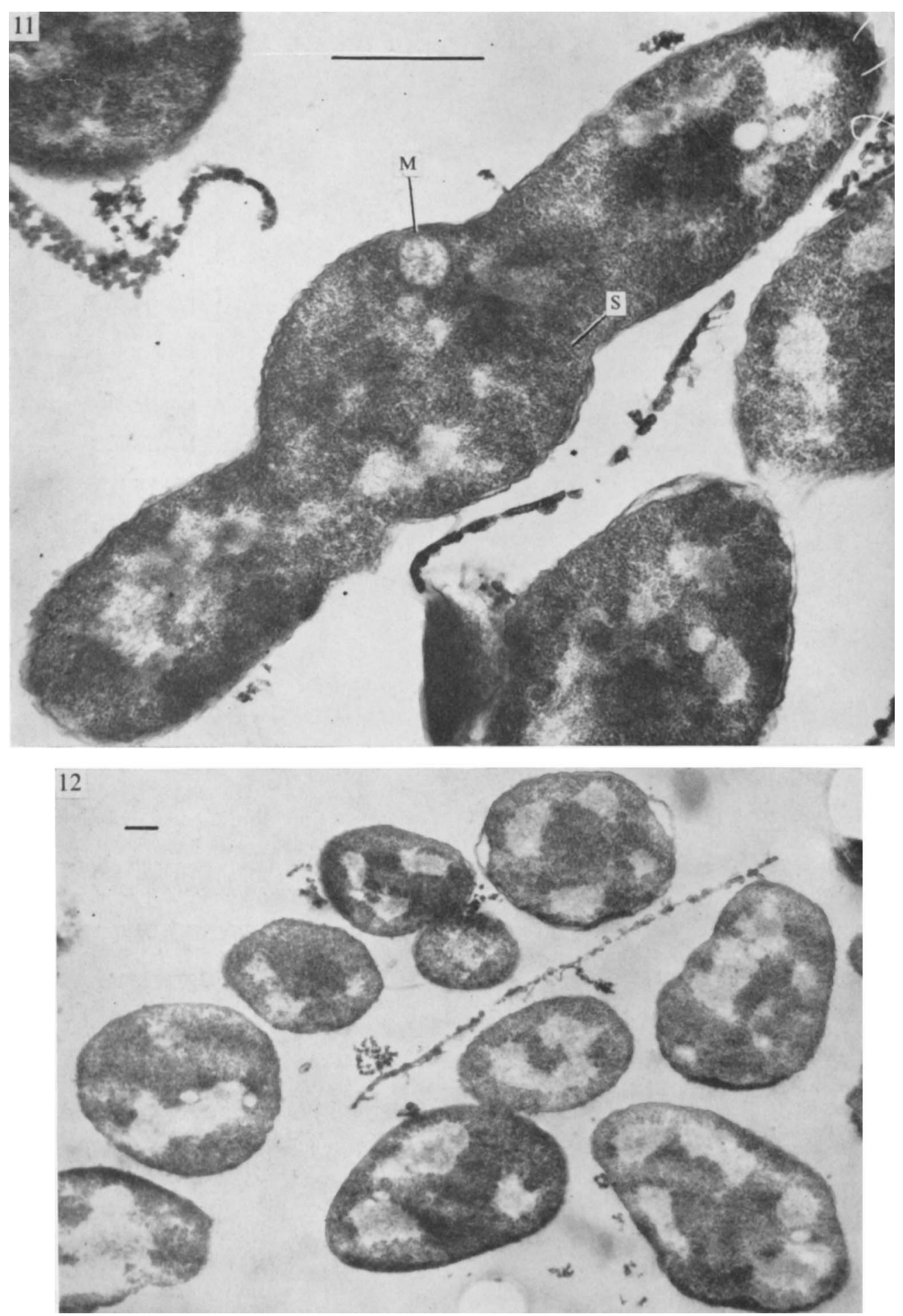


\section{RESULTS}

Arthrobacter marinus routinely went through a morphological change when an $\mathrm{I} 8 \mathrm{~h}$. early stationary phase culture (Pl. I, fig. I) was placed in fresh nutrient medium and incubated for $4.5 \mathrm{~h}$. (Pl. I, fig. 2). When incubated in a medium containing $4 \times 1 \mathrm{IO}^{-4} \mathrm{M}$-nickel the bacteria initially changed in shape and phase density but not in size (Pl. I, fig. 3 to 5). Further incubation produced a marked change in the size, shape and internal morphology ( $\mathrm{Pl}$. I, fig. 6,7 ). After $10.5 \mathrm{~h}$. they were 10 to $15 \mu \mathrm{m}$. in diam. while approximately $60 \%$ of the internal contents appeared as intracellular space (Pl. I, fig. 8). Not all the organisms underwent this morphological change, which was presumably a result of continued growth without division.

Thin sections of normal Arthrobacter marinus after $3 \mathrm{~h}$. at $25^{\circ}$ in nutrient medium without nickel are illustrated in Pl. I, fig. 9. The nuclear material appeared as fine, evenly dispersed and uniformly sized filaments. The ribosomes were densely packed within the cytoplasm and dispersed at random. The outer membrane was composed of three layers approximately I $5 \mathrm{~nm}$. thick, and a double-track plasma membrane approximately $7.5 \mathrm{~nm}$., closely adhering to the cell wall.

Around the periphery were small blebs approximately $0.05 \mu \mathrm{m}$. in diam. These structures consisted of a double-track membrane continuous with and originating from the outer membrane (Pl. I, fig. IO), and could not be traced to the plasma membrane. Occasionally they appeared extended, protruding about 0.15 to $0.3 \mu \mathrm{m}$., resembling a series of blebs connected in tandem.

After $\mathrm{I} h$. incubation with $4 \times 1 \mathrm{IO}^{-4} \mathrm{M}$-nickel the nuclear material and ribosomes appeared unchanged in consistency and distribution from the normal bacteria. The outer membrane became altered in some areas with a loss of the inner dense layer which changed to a double track cell wall (Pl. 2, fig. II). No change was noted in the plasma membrane nor in the mesosomes present. The cell shape was irregular with an occasional organism containing an intracellular space (P1. 2, fig. 12). The blebs still occurred mainly as individual units with an occasional extended form protruding.

The organisms and intracellular spaces were larger and the organisms more irregular in shape after $2 \mathrm{~h}$. with nickel (Pl. 3, fig. I3). The nuclear material and ribosomes remained unchanged in appearance and distribution. The intracellular space resembled that of a plasmolysing organism (Mitchell \& Moyle, 1956). The plasma membrane did not encircle the space but retracted from the wall, leaving the intracellular space surrounded by plasma membrane on one side and wall on the other. The inner dense layer of the wall was evident in some areas.

After $3 \mathrm{~h}$. incubation little change occurred except that the number of mesosomes, now more evident along the periphery of the cytoplasm, was increased. The remaining inner dense layer of the wall decreased further with the double track outer membrane predominating. The light zone between the double track of the $12 \mathrm{~nm}$. thick wall and the double track of the plasma membrane, $8 \mathrm{~nm}$. thick, increased. The entire envelope measured approximately

In Plates 2 to 5 the cultures were grown in the nutrient medium for $3 \mathrm{~h}$. at ambient temperature, the culture was brought to $4 \times 10^{-4} \mathrm{M}$-nickel and aliquots removed after further incubation for the periods indicated.

Plate 2

Fig. I I, I2. Thin sections of Arthrobacter marinus cells grown in the presence of nickel for I h. 

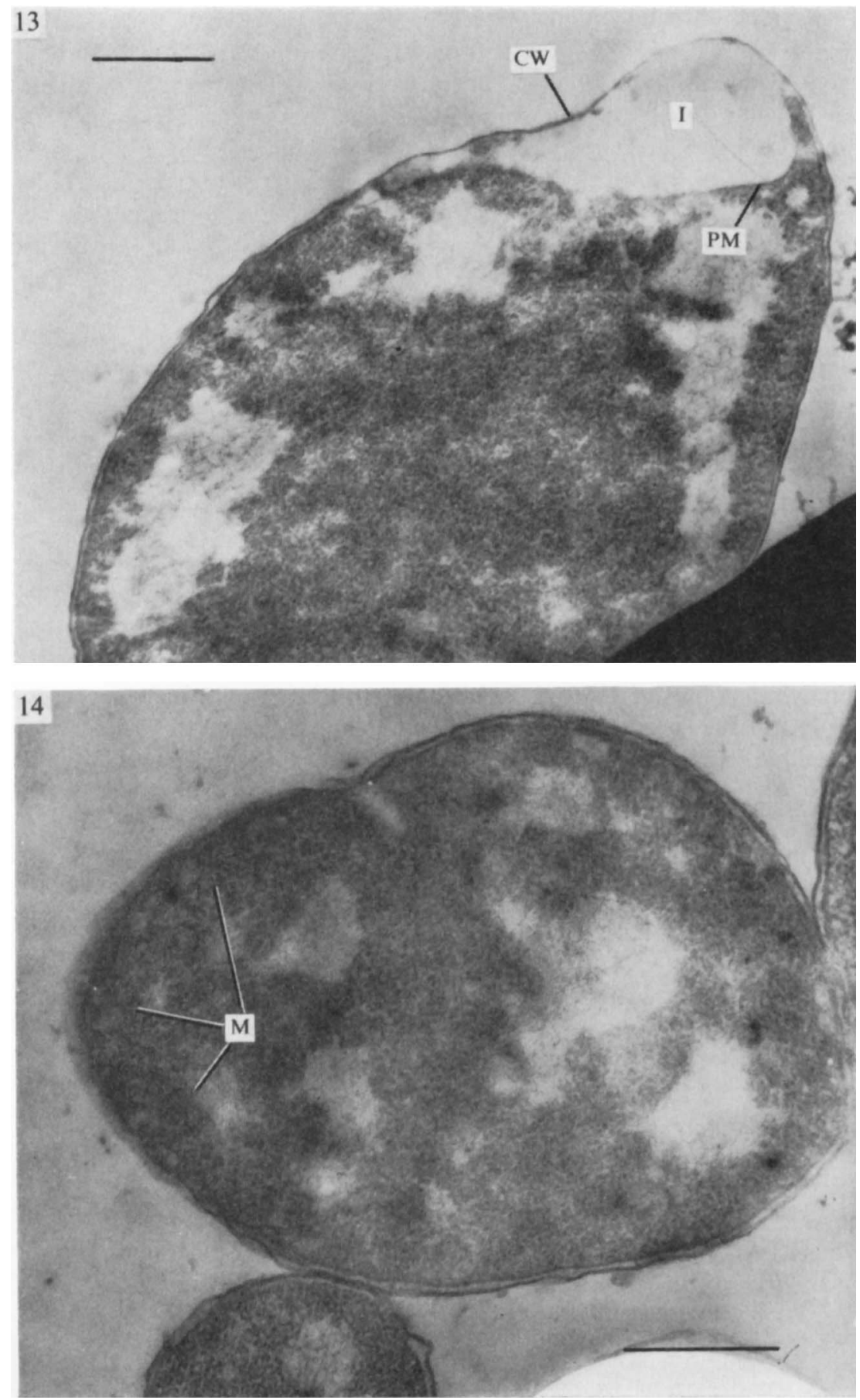

Plate 3

Fig. 13. Section of cell grown in the presence of nickel for $2 \mathrm{~h}$.

Fig. I4. Section of cell grown in the presence of nickel for $3 \mathrm{~h}$. 

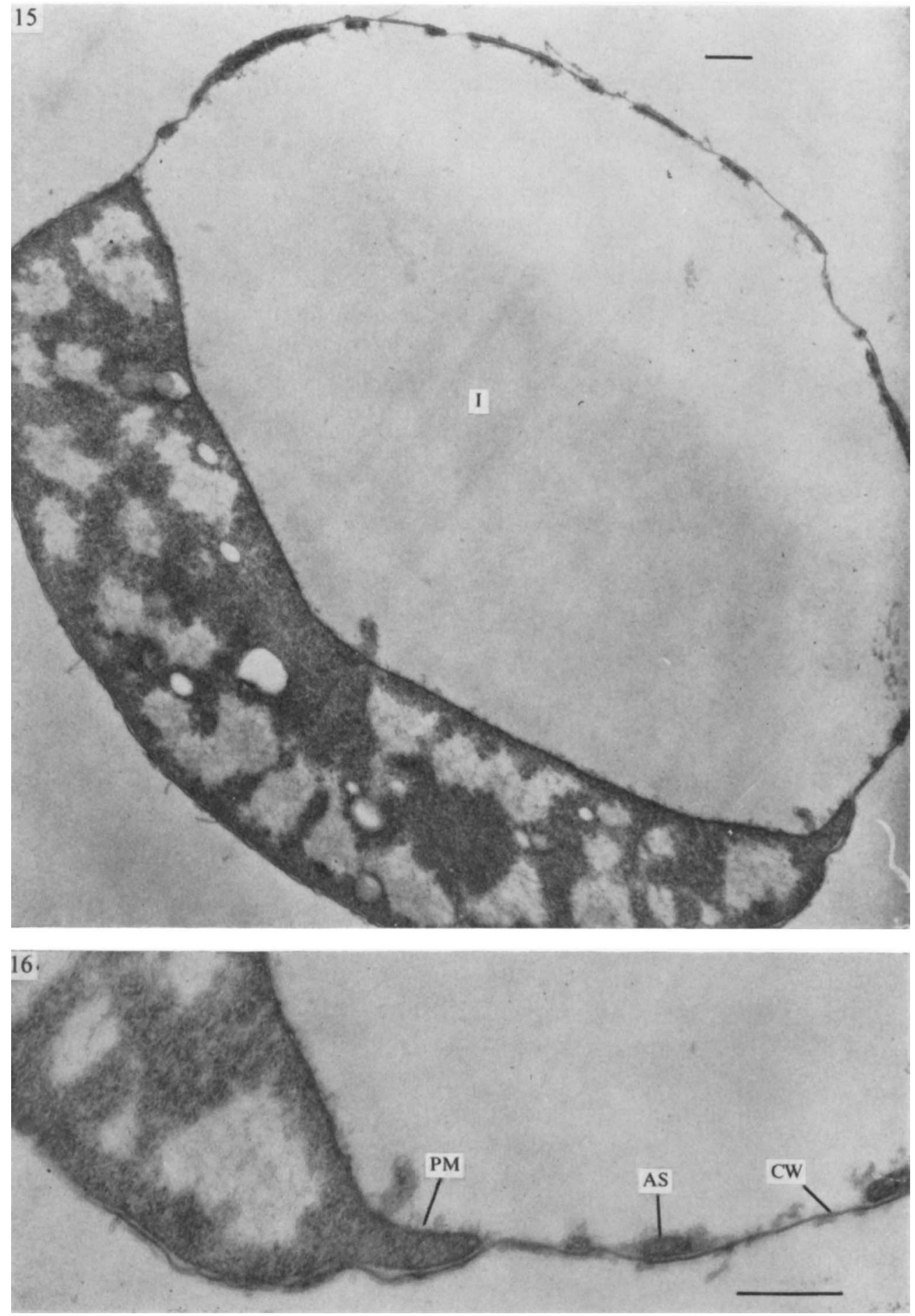

Plate 4

Fig. 15. Section of cell grown in the presence of nickel for $6 \mathrm{~h}$.

Fig. 16. Enlargement of a portion of Fig. 15. 
$35 \mathrm{~nm}$. thick (Pl. 3, fig. I4) as opposed to approximately $25 \mathrm{~nm}$. in the normal organism. The wall decreased by approximately $3 \mathrm{~nm}$. in thickness as the two double tracks separated from each other.

After $6 \mathrm{~h}$. the organisms were greatly plasmolysed with the intracellular space occupying most of the total volume (Pl. 4, fig. I5). The nuclear material was found at numerous locations throughout the cytoplasm and retained its fine filamentous structure. The ribosomes were prominent and evenly dispersed throughout the cytoplasm. Vacuoles delineated by a single membrane occurred. The wall was mainly composed of a double-track membrane with only the inner dense layer appearing occasionally where the wall and the plasma

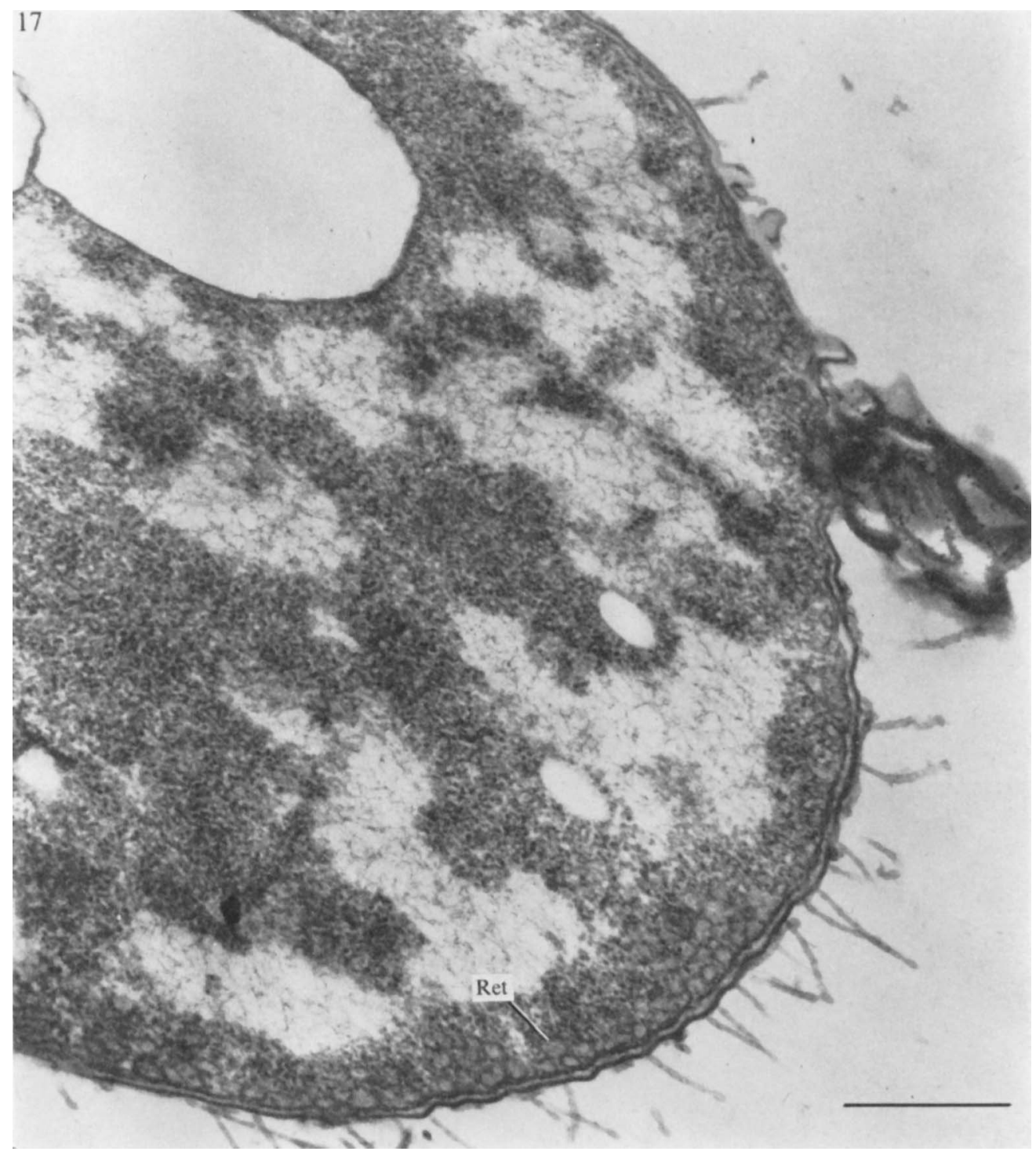

Plate 5

Fig. 17. Portion of a cell grown in the presence of nickel for $6 \mathrm{~h}$. 
membrane were in contact. A number of rounded structures, surrounded by a double-track membrane with an internal reticulated structure, appeared adhering to the inside of the wall away from the crescented cytoplasm. These structures may be remnants of the cytoplasm adhering to the wall. The blebs were evident along the entire wall, even in areas where the plasma membrane and wall were not in contact. Fig. I6, an enlargement of Pl. 4, fig. I5, shows the plasma membrane separated from the wall but remaining in contact with the cytoplasm. Many showed a large degree of reticulation along the periphery of the cytoplasm where the membrane was in contact with the wall. These reticulations were not seen where the cytoplasmic membrane was associated with the intracellular space. In some, the blebs were more numerous and mainly 0.15 to $0.3 \mu \mathrm{m}$. long (Pl. 5, fig. 17).

\section{DISCUSSION}

The large intracellular spaces were maintained by using appropriate osmotic support during fixation and subsequent steps, prior to dehydration and embedding, thus avoiding gross alterations in morphology. When fixed and processed without such osmotic support, the enlarged organisms behave as osmometers, losing their crescent shape and suffering dilution of the cytoplasm or rupture of the plasma membrane with release of cytoplasm into the intracellular space.

Nickel has been placed above magnesium, calcium and manganese in an 'avidity series' based on their reactivity in biological systems (Albert, I958). Even though magnesium is the most common metal cofactor for enzymes whose metal requirements have been determined (Vallee, I960), in a number of these enzymes other metals, i.e. $\mathrm{Mn}, \mathrm{Co}, \mathrm{Cu}, \mathrm{Ni}$ and $\mathrm{Zn}$, are able to replace it in vitro (Starkey, 1955). Some of these metals simultaneously increase the magnesium requirement for growth, stabilize the cell and prevent leakage of magnesium (Webb, 1966). Adiga, Sastry, Venkatasubramaniam \& Sarma (196I) have suggested that zinc and nickel induce a magnesium deficiency, since magnesium was able to reverse the effects of the two metals on growth. A magnesium deficiency produces morphological alteration in both Gram-positive and Gram-negative bacteria with the formation of filaments (Webb, I949; Brock, 1962).

Exponentially growing bacteria, under normal conditions, have a high density of ribosomal particles in the cytoplasm (Murray, 1960) and magnesium is important in their stability (McCarthy, 1962). Bacteria grown under magnesium deficiency contain ribosomes reduced in size and abundance (Morgan, Rosenkranz, Chan \& Rose, 1966; Kennell \& Kotoulas, 1967), and the primary effect of magnesium starvation is on the content of functional ribosomes (Marchesi \& Kennell, 1967). The electron micrographs of enlarged Arthrobacter marinus grown with nickel (P1. 4, fig. 15, 17) show the ribosomes to be normal and evenly distributed through the cytoplasm despite the enlarged size, so there is no indication of magnesium deficiency on the basis of gross ribosomal morphology.

The nuclear material appeared in an increased number of sites within the cytoplasm by the end of the $6 \mathrm{~h}$. growth with nickel. The ultrastructure had not changed from the normal nor did it appear to be diluted as a result of reduced synthesis.

The genus Arthrobacter is noted for its unusual growth response under routine culture methods (Conn \& Dimmick, I947; Mulder, 1964). Normal cells change from coccoid in stationary phase to rods in the logarithmic phase. In $A$. crystallopoietes this is not due to changes in gross chemical composition of the wall but rather to changes in the degree of polymerization of the polysaccharide backbone of the peptidoglycan (Krulwich, Ensign, Tipper \& Strominger, 1967a) and to the degree of cross-linking of the peptides (Krulwich 
Ensign, Tipper \& Strominger, $1967 b$ ), both being greater in the rod form. Structural alteration of the outer envelope occurs during growth. The large size and osmotic sensitivity of enlarged A. marinus suggest that the wall components which are responsible for cellular structure are altered.

The mucopeptide layer seemingly confers strength and shape to the wall and is involved in the initial stages of septum formation and division (Steed \& Murray, 1966). The walls in normal logarithmic phase cells of Arthrobacter marinus were multilayered with three dense layers whereas those of the enlarged forms had only two dense layers. The loss of the inner dense layer resembles the $3 \mathrm{~nm}$. mucopeptide layer associated with spheroplast formation (Murray, 1968). The measurement and relationship of the two outer dense layers appeared to be little?affected.

Associated with this loss in the mucopeptide layer was an increase in the light zone between the plasma membrane and the wall. The entire envelope increased in thickness from 25 to $35 \mathrm{~nm}$. after $6 \mathrm{~h}$. with nickel. This increase appeared in the light zone and was greater than simply the loss of the $33 \mathrm{~nm}$. mucopeptide layer. The relationship between the loss of the mucopeptide layer and the increase in this zone is unknown; the function of the plasma membrane and structure of the wall appear to be affected by a disruption in this zone (Murray, 1968).

Eagon, Simmons \& Carson (1965) demonstrated divalent cations in the wall of Pseudomonas aeruginosa. These cations may function in maintaining the integrity of the wall (Asbell \& Eagon, I966) and additionally in either activating or inhibiting enzymes associated with the wall (Murray, 1968). Nickel may compete with and replace these cations causing a disorganization of the close relationship between various enzymes, which in turn produce less mucopeptide and lead to loss of the dense layer in the wall.

Blebs have been noted on the cell surface of untreated bacteria (Bayer \& Anderson, 1965; Wiebe \& Chapman, I968 $a, b$ ) and increased bleb formation has been associated with alterations in the wall as a result of the action of polymyxin B (Koike, Iida \& Matsuo, 1969), lysozyme (Miller, Zsigray \& Landman, I967) and growth in suboptimal amounts of lysine by a lysine-requiring mutant (Knox, Vesk \& Work, 1966). The greater the effect the agent had on the wall, the more pronounced the degree of bleb formation. With Arthrobacter marinus, under the stress of nickel, the blebs greatly increased in length and number after $6 \mathrm{~h}$. incubation, when the gross morphology was greatly affected.

Bayer (1967) proposed that extrusion of wall in Escherichia coli following osmotic shock was the result of cytoplasmic forces on the outer layer of the wall. It seems unlikely that in this study, and in that of Wiebe \& Chapman $(1968 a, b)$, that bleb formation was due to an osmotic artefact of preparation because iso-osmotic solutions were used during the preparative process. The origin of the blebs cannot be traced to the contour of the protoplasmic membrane; they appear to be derived from the outer layers of the double track in the wall.

Bleb formation on the wall may result from unbalanced wall growth (Knox et al. 1966). In normal logarithmic Arthrobacter marinus the blebs may be associated with a slight disorganization in the wall-synthesizing mechanisms. The increased bleb formation in the nickel induced megalomorph may reflect a greater disruption of wall synthesis shown by a loss of the inner dense layer and an increase in the space between the wall and the cytoplasmic membrane.

The bacteria were still capable of forming mesosomes when grown with nickel; after $3 \mathrm{~h}$. there were more mesosomes along the periphery. The reticulation in the cytoplasm of the $6 \mathrm{~h}$. Arthrobacter marinus may be the result of an accumulation of mesosomes in the cytoplasm in contact with the wall. 
The plasmolysed appearance may be due to the filling of the intracellular space by large molecular weight compounds produced by the cell rather than true plasmolysis. This material would have to be large enough not to diffuse through the wall and may be a wall constituent. This material may result from a disruption of the plasma membrane-wall relationship, or from an alteration in the polymerizing-depolymerizing enzyme interaction associated with wall production. The accumulated material would fill the intracellular space and produce pressures on the wall to maintain the spherical shape. The material is not electron-dense as it is not evident on the electron micrographs.

This work was supported in part by grants from the Office of Naval Research (N-000I468-C-0268), the Water Supply and Pollution Control Administration of the Department of the Interior (WP-00650-03), and National Institutes of Health (HE 06214).

\section{REFERENCES}

Adiga, P. R., Sastry, K. S., Venkatasubramaniam, V. \& Sarma, P. S. (196I). Interrelationships in traceelement metabolism in Aspergillus niger. Biochemical Journal 81, 545-550.

AlBerT, A. (1958). Metal binding agents in chemotherapy: The activation of metals by chelation. Symposia of the Society for General Microbiology 8, 1 1 2-138.

Asbell, M. A. \& EAGON, R. G. (1966). Role of multivalent cations in the organization, structure and assembly of the cell wall of Pseudomonas aeruginosa. Journal of Bacteriology 92, 380-387.

Bassur, P. K. \& Gilman, J. P. W. (1967). Morphologic and synthetic response of normal and tumour muscle cultures to nickel sulfide. Cancer Research 27, $1168-117 \%$.

BAYER, M. E. (1967). Response of cell walls of Escherichia coli to a sudden reduction of the environmental osmotic pressure. Journal of Bacteriology 93, I I04-I 112.

BAYER, M. E. \& ANDERSON, T.F. (1965). The surface structure of Escherichia coli. Proceedings of the National Academy of Sciences of the United States of America 54, I592-1 599.

Brock, T.D. (1962). Effects of magnesium ion deficiency on Escherichia coli and possible relation to the mode of action of novobiocin. Journal of Bacteriology 84, 679-682.

Cobet, A. B., Wirsen, C. \& Jones, G. E. (1970). The effect of nickel on a marine bacterium, Arthrobacter marinus sp. nov. Journal of General Microbiology 62, 159-I69.

ConN, H. J. \& Dimmick, I. (1947). Soil bacteria similar in morphology to Mycobacterium and Corynebacterium. Journal of Bacteriology 54, 29I-303.

Eagon, R. G., Simmons, G. P. \& CaRson, K. J. (1965). Evidence for the presence of ash and divalent metals in the cell wall of Pseudomonas aeruginosa. Canadian Journal of Microbiology Ir, 104r-1042.

Hackett, R. L. \& Sunderman, F. W., JUN. (I968). Pulmonary alveolar reaction to nickel carbonyl: Ultrastructural and histochemical studies. Archives of Environmental Health 16, 349-362.

Hackett, R. L. \& Sunderman, F. W., JUN. (I969). Nickel carbonyl: Effects upon the ultrastructure of hepatic parenchymal cells. Archives of Environmental Health 19, 337-343.

Kennell, D. \& Kotoulas, A. (1967). Magnesium starvation of Aerobacter aerogenes. IV. Cytochemical changes. Journal of Bacteriology 93, 367-378.

KNOX, K. W., VESK, M. \& WORK, E. (I966). Relation between extracted lipopolysaccharide complexes and surface structures of a lysine-limited culture of Escherichia coli. Journal of Bacteriology 92, I $206-1217$.

KoIKe, M., IIDA, K. \& MATSUO, T. (I969). Electron microscopic studies on mode of action of polymyxin. Journal of Bacteriology 97, 448-452.

Krulwich, T. A., Ensign, J. C., Tipper, D. J. \& Strominger, J. L. (1967a). Sphere-rod morphogenesis in Arthrobacter crystallopoietes. I. Cell wall composition and polysaccharides of the peptidoglycan. Journal of Bacteriology 94, 734-740.

Krulwich, T. A., Ensign, J. C., Tipper, D. J. \& Strominger, J. L. (1967b). Sphere-rod morphogenesis in Arthrobacter crystallopoites. II. Peptides of the cell wall peptidoglycan. Journal of Bacteriology 94, 74 I750.

Lyman, J. \& Fleming, R. H. (1940). Composition of sea water. Journal of Marine Research 3, I34-146.

Marchesi, S. L. \& Kennell, D. (1967). Magnesium starvation of Aerobacter aerogenes. III. Protein metabolism. Journal of Bacteriology 93, 357-366.

MCCARTHY, B. J. (1962). The effects of magnesium starvation on the ribosome content of Escherichia coli. Biochimica et biophysica acta 55, 880-888. 
Miller, I. L., Zsigray, R. M. \& LaNdman, O. E. (1967). The formation of protoplasts and quasi-spheroplasts in normal and chloramphenicol-pretreated Bacillus subtilis. Journal of General Microbiology 49, 513-525.

Mitchell, P. \& Moyle, J. (1956). Osmotic function and structure in bacteria. Symposia of the Society for General Microbiology 6, I50-180.

Morgan, C., Rosenkranz, H. S., Chan, B. \& Rose, H. M. (1966). Electron microscopy of magnesiumdepleted bacteria. Journal of Bacteriology 9I, 891-895.

Mulder, E. G. (1964). Arthrobacter. In Principles and Applications in Aquatic Microbiology, pp. 254-279. Edited by H. Heukelekian \& N. Dondero. Rudolfs Research Conference Proceedings, I963. New York: Wiley:

Murray, R. G. E. ( 1960 ). The internal structure of the cell. In The Bacteria, vol. I, pp. 35-96. Edited by I. C. Gunsalus \& R. Y. Stainier. New York: Academic Press.

Murray, R. G. E. (I968). Bacterial cell wall anatomy in relation to the formation of spheroplasts and protoplasts. In Microbial Protoplasts, Spheroplasts and L-Forms, pp. I-I 8. Edited by L. B. Guze. Baltimore: William \& Wilkins Co.

Ryter. A. \& Kellenberger, E. (1958). Étude au microscope électronique de plasmas contenant de l'acide désoxyribonucleique. I. Les nucléoides des bactéries en croissance active. Zeitschrift für Naturforschung 136, 597-599.

STARKEY, R. L. (1955). Relations of micronutrients to development of micro-organisms. Soil Science 79, $1-14$.

Stefd, P. \& Murray, R. G. E. (1966). The cell wall and cell division of Gram-negative bacteria. Canadian Journal of Microbiology 12, 263-270.

VALIEI, B. L. (1960). Metal and enzyme interactions: Correlation of composition, function and structure. In The Enzymes, vol. 3, pp. 225-276. Edited by P. D. Boyer, H. Lardy \& K. Myrback. New York: Academic Press.

WeBB, M. (1949). The influence of magnesium on cell division. II. The effect of magnesium on the growth and cell division of various bacterial species in complex media. Journal of General Microbiology 3, $410-$ 417.

WeBB. M. (1966). The utilization of magnesium by certain Gram-positive and Gram-negative bacteria. Journal of General Microbiology 43, 40I-409.

Wiebe. W. J. \& Chapman, G. B. (1968a). Fine structure of selected marine pseudomonads and achromobacters. Journal of Bacteriology 95, $1862-1873$.

WIEBE. W. J. \& ChAPMAN, G. B. (I968 $b$ ). Variation in the fine structure of a marine achromobacter and a marine pseudomonad grown under selected nutritional and temperature regimes. Journal of Bacteriology 95, I874-1 886. 